\title{
PUMP AND DOWN IN JIWASRAYA INVESTATION AND THE ABSENCE OF ISLAMIC ECONOMY LAW PRINCIPLES
}

\author{
Ali Geno Berutu \\ Institut Agama Islam Negeri Salatiga, Indonesia \\ Email: ali_geno@ymail.com
}

\section{Abstract}

The case of PT. Asuransi Jiwasraya (Persero) investment once became public attention. Not only does it harm its customers, the country also must bear the company's loss. This loss is caused by the investment practice into low-quality stocks. The company neglected the good investment principles and prioritized more on the personal interest. This article aims to describe and define the pump and down phenomena in the investment of PT. Asuransi Jiwasraya. To top it off, the article analyzes the pump and down phenomena based on the Islamic economy law principles. This is a doctrinal legal research with case study approach. The results show that pump and down is a transaction activity of an effect in manipulative way. This model is characterized by rising price (uptrend) because of a series of stock purchase transaction in a fairly big amount so the rising reaches the highest price level, then the reduced price is too significant. They aim at gaining bigprofit so they can re-purchase the stock in a cheaper price. This pump and down phenomena in PT. Asuransi Jiwasraya investment case is not in line with the Islamic law principles. The investment model in this schem a contains several elements i.e. maisir, najasy, gharar, ghisysy, ibktikar, and tadlis.

Kasus investasi PT. Asuransi Jiwasraya (Persero) sempat menjadi sorotan publik. Selain merugikan nasabah, negara juga harus menanggung kerugian perusahaan. Kerugian ini muncul akibat praktik investasi pada saham kualitas rendah. Perusahaan disinyalir mengabaikan prinsip-prinsip investasi yang baik dan lebih mengedepankan kepentingan pribadi. Artikel ini bertujuan mendeskripsikan fenomena pump and down dalam investasi PT. Asuransi Jiwasraya. Artikel ini juga bertujuan mesdeskripsikan pump and down dalam kasus Jiwasraya. Artikel inijuga menganalisis fenomena pump and down tersebut berdasarkan prinsip-prinsip hukum ekonomi syariah. Artikel ini merupakan hasil penelitian bukum doctrinal dengan pendekatan studi kasus. Hasil penelitian ini menunjukkan bahwa Pump and Dump merupakan aktivitas transaksi suatu Efek secara manipulative. Model transaksi ditandai dengan naiknya 
harga (uptrend) karena adanya serangkaian transaksipembelian saham dalam jumlah yang cukup banyak sehingga harga naik mencapai level harga tertinggi. Kemudian penurunan harga yang sangat signifikan. Tujuannya untuk meraih keuntunganyang besar dan bisa membeli kembali saham tersebut dengan harga murah. Fenomena pump and down dalam kasus investasi PT. Asuransi Jiwasraya tidak sejalan dengan prinsip-prinsip bukum Islam. Model investasi dengan skema ini mengandung unsur maisir, najasy, gharar, ghisysy, ihktikar, dan tadlìs.

Keywords: investation, Islamic economy law, pump and down.

\section{Introduction}

Jiwasraya insurance is currently becoming a hot topic of discussion among Indonesians. The problem experienced by Jiwasraya is not trivial in which the inability of the oldest insurance in Indonesia to pay for the insurance policy product of the JS Saving Plan reaching 12.4 trillion rupiah ${ }^{1}$. The JS Saving Plan product policy is a life insurance product as well as an investment offered through banking or bancasurrance.

As we know from the information and news available so far, Jiwasraya Insurance is experiencing liquidity pressure (the ability to pay debts) which makes the State-Owned Enterprises' equity (assets) recorded negative up to 23.92 trillion rupiah in September 2019 and this resulted into the capital adequacy ratio for general insurance and life insurance companies based on Financial Services Authority regulation (known as $P$-OJK) and it is about $120 \%$. Thus, Jiwasraya insurance requires a capital injection of up to 32.89 trillion to become a healthy insurance company in accordance with the $\mathrm{P}-\mathrm{OJK} \mathrm{K}^{2}$.

Jiwasraya customer default case has actually occurred since the $2000 \mathrm{~s}^{3}$. From the data compiled by CNN Indonesia, Jiwasraya has experienced problems starting from 2006 in which at that time the equity of this State-Owned Enterprise's insurance was recorded at minus 3.29 trillion. This data was obtained from the Ministry of State-Owned Enterprises and Financial Services Authority. In 2008, the Supreme Audit Agency (BPK) gave a disclaimer on the audit results for the

1 “Bobrok dari 2004, Ini Kronologi Jiwasraya Hingga Default," diakses 16 Januari 2020,https://www. cnbcindo nesia.com/market/20191228185156-17-126264/bobrok-dari-2004-ini-kronologi-jiwasrayahingga-default

2 “Astaga! Rasio Kecukupan Modal Jiwasraya Minus 850\%," diakses 17 Januari 2020, https://www. cnbcindonesia .com/market/20191218160147-17-124158/astaga-rasio-kecukupan-modal-jiwasrayaminus- 850

3 CNN Indonesia, “Kronologi Kasus Jiwasraya, Gagal Bayar Hingga Dugaan Korupsi,” 2020, https:/ / www.cnn indonesia.com/ekonomi/20200108111414-78-463406/kronologi-kasus-jiwasraya-gagalbayar-hingga-dugaan-korupsi 
2006 and 2007 financial statements because the information regardingJiwasraya's capital reserves could not be trusted. Jiwasraya experienced financial deficit in 2008 , it increased by 3.29 trillion in 2006, 5.7 trillion in 2008, and 6.3 trillion in 2009.

In 2010 to 2012, Jiwasraya implemented a reinsurance scheme and recorded a surplus of 1.3 trillion at the end of 2011. In 2012, the Capital Market and Financial Institution Supervisory Agency issued a license for JS Proteksi Plan products on December $18^{\text {th }}, 2012$. JS Proteksi Plan was marketed in cooperation with banks (bancassurance). This product also adds the weakness to the company because it offers high interest, $9 \%$ to $13 \%$ per year.

In 2014, the State-Owned Insurance financial problems had not been resolved but Jiwasraya became a sponsor for the English football club Manchester City. In 2017, the financial condition of Jiwasraya insurance company seemed to improve. This is indicated by the positive financial statements of Jiwasraya in 2007, recording insurance premium income from the $J S$ Saving Plan product reaching IDR 21 trillion, thus this state company earned IDR 2.4 trillion, increasing $37.64 \%$ from 2016.

In 2018, the Director of Insurance Supervision of Financial Service Authority issued a letter of approval for the 2016 premium reserves of 10.9 trillion rupiah. This year, the customer of the $J S$ Saving Plan began to cash out their insurance due to allegations of irregularities in the company's management. The indication of the irregularity is correct because the result of the audit of the Public Accountant Firm and price Waterhouse Coopers $(\mathrm{PwC})$ on the 2017 financial statements corrected the interim financial statements from a profit of IDR 2.4 trillion to only IDR 428 billion. In August 2018, Minister of State-Owned Enterprises Rini Soemarno gathered a board of directors to explore the company's potential for default. He also asked BPK and the Financial and Development Supervision Agency (BPKP) to carry out an investigate audit of Jiwasraya.

In October and November 2018, Jiwasraya's liquidity problems began to be noticed by the public. The company announced that it was unable to pay claims for insurance policy of $J S$ Saving Plan customers amounting to IDR 802 billion. In November, the results of the General Meeting of Shareholders appointed Hexana Tri Sasongko as the President Director and he revealed that Jiwasraya needed funds of IDR 32.89 trillion to meet the solvency ratio of 120 percent. In addition to that, the company's assets were recorded at only IDR 23.26 trillion while its liabilities reached IDR 50.5 trillion. As a result, Jiwasraya's equity was negative around IDR 27.24 trillion. Meanwhile, liabilities (debts) from problematic JS 
Saving Plan products were recorded at IDR 15.75 trillion.

Figure 1 Travel Map of Jiwasraya Insurance

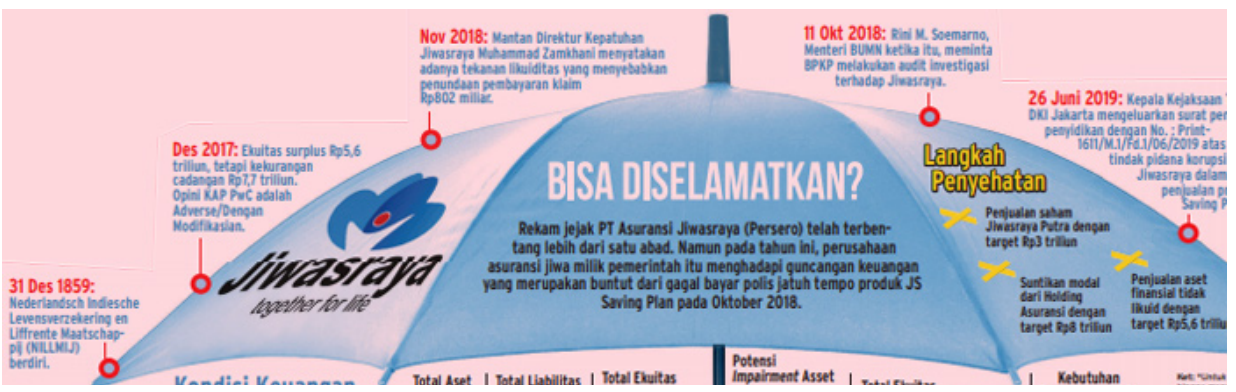

Source: https://finansial.bisnis.com/ (Accessed on 16-01-2020)

In the second government cabinet, President Joko Widodo appointed Erick Thohir as the first person in the Ministry of State-Owned Enterprises. In November 2019, Erick Thohir as Minister of State-Owned Enterprises reported indications of fraud at Jiwasraya to the Attorney General's Office (AGO). This was done after the government looked in detail at the financial statements of companies that were considered not transparent. The Ministry of State-Owned Enterprises suspects that there is an unhealthy investment scheme in Jiwasyara insurance with a large enough capital placement in shares that have a small market capitalization (speculation) in the portfolio of this State-Owned Enterprises, this is one of the causes of Jiwasraya's claim default.

Table 1. A list of shares that becomes Jiwasraya insurance portfolio

\begin{tabular}{lll}
\hline No & \multicolumn{1}{c}{ Direct Placement } & \multicolumn{2}{c}{ Indirect Placement } \\
\hline $\mathbf{1}$ & PT Semen Baturaja Tbk. (SMBR) & $\begin{array}{l}\text { PT Prima Cakrawala Abadi Tbk. } \\
\text { (PCAR) }\end{array}$ \\
\hline $\mathbf{2}$ & PT SMR Utama Tbk. (SMRU) & PT Eureka Prima Jakarta Tbk. (LCGP) \\
\hline $\mathbf{3}$ & PT PP Properti Tbk. (PPRO) & $\begin{array}{l}\text { PT Graha Andrasentra Propertindo Tbk. } \\
\text { (JGLE) }\end{array}$ \\
\hline $\mathbf{4}$ & $\begin{array}{l}\text { PT Bank BPD Jawa Barat dan Banten } \\
\text { Tbk. (BJBR) }\end{array}$ & PT Pool Advista Finance Tbk. (POLA) \\
\hline $\mathbf{5}$ & $\begin{array}{l}\text { PT Astrindo Nusantara Infrastruktur } \\
\text { Tbk. (BIPI) }\end{array}$ & PT Trada Alam Minera Tbk. (TRAM) \\
& &
\end{tabular}

Source: https://finansial.bisnis.com/(Accessed on 16-01-2020) 
Table 2. A list of stock returns that are part of Jiwasraya Insurance Portfolio

\begin{tabular}{|c|c|c|c|}
\hline \multicolumn{4}{|c|}{ The Performance of Shares that Jiwasraya has collected in the last 3 years } \\
\hline Issuer & $\begin{array}{l}\text { Performance } \\
\text { of Shares } 2017\end{array}$ & $\begin{array}{l}\text { Performance of } \\
\text { Shares } 2018\end{array}$ & $\begin{array}{l}\text { Performance of } \\
\text { Shares } 2019\end{array}$ \\
\hline $\begin{array}{l}\text { PT Semen Baturaja Tbk. } \\
\text { (SMBR) }\end{array}$ & $+36.46 \%$ & $-53.89 \%$ & $-74.78 \%$ \\
\hline $\begin{array}{l}\text { PT SMR Utama Tbk. } \\
\text { (SMRU) }\end{array}$ & $+41.76 \%$ & $+34.85 \%$ & $-92.31 \%$ \\
\hline $\begin{array}{l}\text { PT PP Properti Tbk. } \\
\text { (PPRO) }\end{array}$ & $-44.13 \%$ & $-37.58 \%$ & $-41.28 \%$ \\
\hline $\begin{array}{l}\text { PT Bank Pembangunan } \\
\text { Daerah Jawa Barat dan } \\
\text { Banten Tbk. (BJBR) }\end{array}$ & $-25.94 \%$ & $-11.12 \%$ & $-39.32 \%$ \\
\hline $\begin{array}{l}\text { PT Astrindo Nusantara } \\
\text { Infrastruktur Tbk. } \\
\text { (BIPI). }\end{array}$ & $+0.00 \%$ & $-29.58 \%$ & $0 \%$ \\
\hline $\begin{array}{l}\text { PT Prima Cakrawala } \\
\text { Abadi Tbk. (PCAR) }\end{array}$ & $+69.33 \%$ & $+2006.30 \%$ & $-79.44 \%$ \\
\hline $\begin{array}{l}\text { PT Eureka Prima Jakarta } \\
\text { Tbk. (LCGP) }\end{array}$ & $-40.74 \%$ & $+62.50 \%$ & $-12.31 \%$ \\
\hline $\begin{array}{l}\text { PT Graha Andrasentra } \\
\text { Propertindo Tbk. (JGLE) }\end{array}$ & $-66.41 \%$ & $-62.41 \%$ & $0 \%$ \\
\hline $\begin{array}{l}\text { PT Pool Advista Finance } \\
\text { Tbk. (POLA) }\end{array}$ & - & $+1529.63 \%$ & $-88.09 \%$ \\
\hline $\begin{array}{l}\text { PT Trada Alam Minera } \\
\text { Tbk. (TRAM) }\end{array}$ & $+44.91 \%$ & $-14.14 \%$ & $-70.59 \%$ \\
\hline
\end{tabular}

Source: https://market.bisnis.com/(Accessed on 16-01-2020)

Besides from the AGO, the Jakarta High Prosecutors' Office has also upgraded the status of examination from search to investigation toward the cases of suspected corruption. In December 2019, the result of the investigation by the Attorney General's Office into the Jiwasraya corruption case stated that there was a violation of the principle of prudence in investing. It is known that Jiwasraya places 95 investment funds in risky assets.

Actually, OJK has written rules regarding the diversification of the insurance company portfolio through POJK No.71 concerning financial soundness of insurance and reinsurance companies with Sharia principles. To maintain financial liquidity, the Financial Services Authority insurance company determines the 
investment composition in the form of cash and banking deposits of at least 10\% of the investment value, government bonds at least 30\%, Bank Indonesia (BI) instruments, State-Owned Enterprises bonds, Non State-Owned Enterprises corporate bonds at least 30\% and placements in portfolio of large cap stocks (blue chips) and mutual funds with a maximum value of $20 \%{ }^{4}$. But if you observe this rule, Jiwasraya has violated the provisions of Financial Services Authority Regulation No. 71 and 72, one of which is by placing investments in stocks and mutual funds of more than $50 \%$ and even, not in large cap stocks (blue chips) but in small cap stocks (penny).

Figure 2. A composition of insurance investment placement
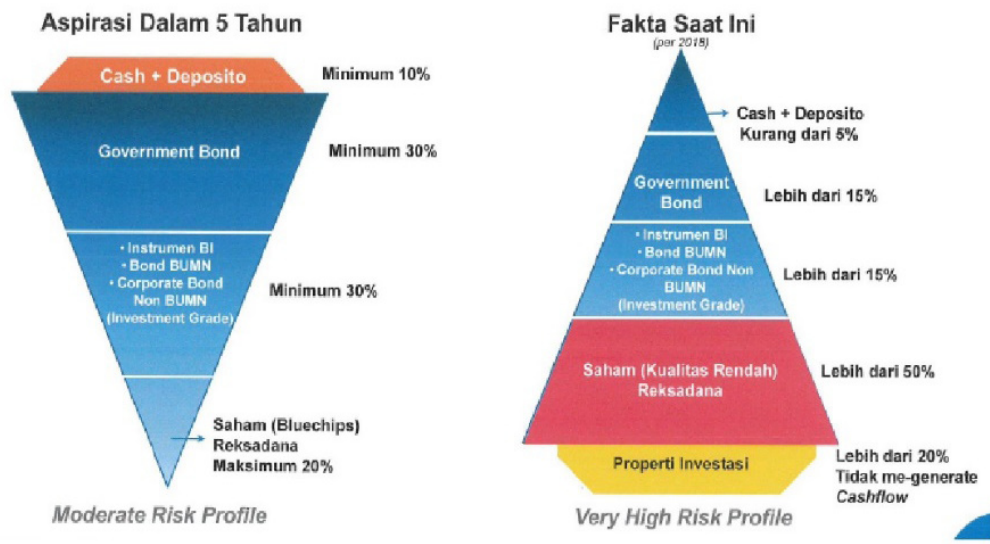

Source: https://market.bisnis.com/ (Accessed on 17-01-2020)

This is the place where the main problem with Jiwasraya Insurance lies in which the composition of the stock and mutual fund portfolios that have exceeded the threshold of the $20 \%$ stipulation of the OJK. Besides, it exceeds the composition of the investment weighting in high risk instruments, Jiwasraya is also wrong in choosing the type of issuer. In POJK No.71, it explains that stocks and mutual funds that can be used as investment options are stocks that have a large market capitalization (blue chips), but in fact Jiwasraya's portfolio placement turns out to be stocks that have a small market capitalization and tend to be fluctuated (rising and falling so fast) and it does not have a good healthy and growing company's base.

4 Wiwiek Mardawiyah Daryanto, Wawan Rahardianto, "Measuring the Financial Health Performance of Life Insurance Company in Indonesia: Case Study During the Period of Before and After the Implementation of Peraturan Otoritas Jasa Keuangan, Nomor 71/POJK.05/2016," IPMI: International Journal of Business Studie 3, no. 2 (2019): 64-71 
Fluctuated shares are often called as penny stocks. This kind of shares can incredibly increase without real corporate actions or it can easily and rapidly drop off without reasons as well. In one day or days, shares that are included into penny stocks can experience top auto reject and bottom auto reject.

From the explanation of Jiwasraya's case, the question for us is about what penny stock is. This is what the author will describe in the discussion chapter of the article. In addition to it, the author will explain as well the legality (legal) aspects of the transaction of penny stocks (speculation) in the view of Islamic law.

\section{Research Methods}

From the preliminary introduction above, a particular research method is needed to answer the research questions in this paper. The research method used in this paper is a normative-empirical legal (applied law research) with a non-judicial case study approach ${ }^{5}$. The normative-empirical legal research referred to in this paper is research that analyzes legal problems in a doctrinal way, such as referring to existing laws and regulations related to financial transactional in Indonesia (literature study) and how the legal reality prevails in a society (real action) in implementing it whether it is in accordance with the wishes of the law. The nonjudicial case study approach in this paper is that this research is not related to the conflict currently being faced by Jiwasraya. So, the focus of this paper is not to examine the legal consequences that will be faced by Jiwasraya's management but how Jiwasraya should manage its company assets so that it does not have a negative effect on other parties. Moreover, it also examines how the legal aspects of investing in speculative stocks from a legal perspective Islam.

\section{Discussion}

If we examine the aforementioned term 'penny stock', then we will have a little trouble in finding specific references related to these penny stocks. We will only find a discussion of stocks in general which we are familiar with as big cap stocks, large-cap stocks and small cap stocks of the term main of the first tier stocks with a large market capitalization advantage (first liner) are also often called capital market activists with the term blue chips such as shares of PT. Semen Indonesia, Inc. (TLKM), PT. Unilever Indonesia, Inc. (UNVR) and others, these stocks are very liquid and are actively traded on stock exchange days.

Mid-Cap Stocks can be said that the stocks in this category are still liquid (actively traded) even though the company's fundamental condition, which is

5 Abdulkadir Muhammad, Hukum dan Penelitian Hukum (Bandung: Citra Aditiya, 2004). 52. 
listed as mid-cap stocks, is still in the developmental stage. The examples of stocks in this category are, PT. Bumi Serpong Damai, Inc. (BSDE), PT. Kalbe Farma, Inc. (KLBF), PT. Japfa Comfeed Indonesia, Inc. (JPFA), PT. Adaro energy, Inc. (ADRO) and others. Finally, stocks that are included in the small-cap stocks category, such as stocks that have market capitalization (market capitalization) of small companies. Usually, stocks like this are the target for capital market speculators to aim at achieving instant profit but also risk borne.

The author tries to translate penny stocks from the research $s /$ he conducted on online media in Indonesia. One of the reasons is CNBC Indonesia, which defines penny stocks as stocks whose increases and decreases are out of the ordinary because the movement of these stocks is engineered by market players with specific objectives and purposes ${ }^{6}$.

The term penny stock which its share increases and decreases so rapidly and in a short time is taken from the term typical Indonesian snack, the so-called "fried snack" which we often find on the side of the road or in public food stalls. It is called penny stock because if its small market capitalization, so it is easy to move the price in the capital market because it does not really need a large amount of capital to make the share price rise or fall. If an investor places too much funds in stock instrument that have a small market capitalization, it will be possible to experience a large enough floating loss in the investor's portfolio. This is what meant by stock speculation by market players on the Indonesia Stock Exchange?

The prohibition of transaction on stocks that have high fluctuation in price movements has bigger risk and it is also great to become a trap for investors whose intentions are to seek profits in the capital market instead of having to accept large potential losses. In this situation, as a consideration for capital market players, the Indonesian Stock Exchange (IDX) often stops trading transactions of a share because it has price movements outside its custom. The characteristics of stocks that fall into the fluctuating stocks category (penny) are as follows:

1. Entering into the list of Unusual Market Activity (UMA)

UMA is the movement of a stock (securities) that occurs out of the ordinary at a certain time. The shares are usually discrete first by the Indonesia Stock Exchange (IDX) because the increase is too extreme for more than two days. The definition of extreme is to go up to the maximum daily (top auto reject), either 20\%,25\%,

6 CNBCIndonesia, "Apa Itu Saham Gorengan? Ini Definisi, Ciri-ciri, dan Tipsnya," diakses 15 Januari 2020, https://www.cnbcindonesia.com/investment/20200102162008-21-127172/apa-itu-sahamgorengan-ini-definisi-ciri-ciri-dan-tipsnya

7 CNBC Indonesia, "Dari Jokowi hingga Sri Mulyani Soroti Saham Gorengan," 2020, https://www. cnbcindo nesia.com /market/20200103092703-17-127301/dari-jokowi-hingga-sri-mulyani-sorotisaham-gorengan 
or $35 \%$ per day, depending on the share price ${ }^{8}$.

As we know for stocks with a price above IDR 5,000/share, the top auto reject stipulation is $20 \%$. For stocks with a price range of IDR 200-5,000, the maximum increase in a day is $25 \%$. Shares with a price range of IDR 50-200 / share are $35 \%$ per day. The purpose of the unusual market activity which the IDX assigns to one particular share is to cool down and serve as a warning to investors to be more careful at the same time in placing their capital in the issuer due to abnormal price movements?.

2. Unreasonable daily transactional volume and value

Its market capitalization is small and is included in the category of two tier (Mid-Cap Stocks) or three-tier stocks (Small-Cap Stocks), but its daily transactional volume and value are very high compared to similar companies, sometimes even similar to blue chip transactions. Market capitalization is a measure of the size of a company, obtained from the number of outstanding shares of the company multiplied by its market price. To compare a company with one or more other similar companies, you should also pay attention to its market capitalization because too much difference will make the comparison of the two stocks unbalanced ${ }^{10}$.

With a small market capitalization and / or limited ownership of retail investors, people who have an interest (dealer) can easily and more cheaply manage penny stocks which become commodities in the capital market.

\section{Unreasonable bids and offers}

Bid queues to buy share at a low price, while the offer (sell) at a high price ${ }^{11}$. Penny stocks are usually traded in large quantities but the bid and offer positions are thin. This means that it is almost certain that at every queue price, both bid and offer, the queue is uneven and often only 1 lot per price, which makes it easier for the dealer to increase the share price.

8 CNBC Indonesia, "Apa Itu Saham Gorengan? Ini Definisi, Ciri-ciri, dan Tipsnya"

9 Dewi Cahya Wulan, Siti Ragil Handayani, dan Ferina Nurlaily, "Analisis Abnormal Return dan Trading Volume Activity Terhadap Pengumuman Unusual Market Activity ( Studi pada Perusahaan yang Terdaftar dalam Pengumuman Unusual Market Activity di BEI Tahun 2015-2017)," Jurnal Administrasi Bisnis (JAB) 61, no. 1 (2018): 175

10 Sawaluddin Siregar, "Perspektif Hukum Islam Mengenai Mekanisme Manipulasi Pasar dalam Transaksi Saham di Pasar Modal," Yurisprudentia 3, no. 2 (2017): 78-80

11 A. Lasmana A. Patoni, "The Effectof Stock Price and Trading Frequency of The Bid-Ask Spread (Empirical Study on A Manufacturing Company Doing Stock Split In Indonesian Stock Exchange During 2009-2014)," Jurnal Akunida 1, no. 2 (2015): 5 
The Financial performance and information of the issuer are not in line with the price increase

Prices that soar up to hundreds of percent in a month are usually not supported by good fundamental company data, meaning that there is a contradiction between the market share price and the actual condition of company. Sometimes its financial performance grows $50 \%$, but it is not infrequently that its performance drops more than $50 \%$ when the price goes up continuously, so that the increase in share prices often does not coincide with the performance and corporate actions announced by the issuer.

\section{Unable to analyze}

Shares that fall into the penny category cannot be analyzed either fundamentally or technically. Financial performance is not as high as its share price increase in the market. Financial ratios and valuations of penny stocks are usually too high compared to its closest competitors, or even unreasonable. In other words, this stock cannot be fundamentally analyzed.

The valuation that is often used to measure the health of a company in the capital market is by using the share Price to book Value (PBV), the ratio of Earning per Share (EPS) and the Price Earning Ratio (PER) which calculates the ratio by dividing the current share price by Earning per Share (EPS) ${ }^{12}$. If the valuation of an issue turns out to be more expensive than similar companies listed on the IDX, it must be a question for us. Examples of shares XXXZ, ZZZX and ZXZX are public companies listed on the IDX, shares of XXXZ and ZZZX have PBV of 1,2 times but shares of ZXZX have PBV of 50 times. Likewise, if we do a technical analysis of penny stocks, technically, the movement of these stocks is also too volatile or it is rarely traded so that it does not raise any technical analysis indicators at all.

\section{Speculation Shares in the View of Islamic Law}

The happiness of living in a world with an abundance of wealth is one of the goals of human life in the world. In Islam, the joy living in the world with good financial capabilities is a recommendation for its adherents. Rasulullah Muhammad SAW once said to be serious in working to achieve a good life in this world without having to forget the hereafter ${ }^{13}$. Allah has reminded Muslims not

12 Debi Carolina, "Analisis Penilaian Kewajaran Harga Saham Dengan Menggunakan Pendekatan Fundamental Pada PT. Panin Sekuritas Tbk," Jurnal Media Wabana Ekonomika 15, no. 2 (2018): 22-34

13 Didin Hafidudin dan Hendri Tanjung, Manajemen Syariah dalam Praktik Jakarta: Gema Insani Press, 2003), 1. 
to leave a weak generation (QS. An-Nisā’: 9). According to Didin Hafidhussin, Professor of Islamic religion of IPB, what is meant by weak in verse 9 of Surah An-Nisā is weak in four ways where one of which is economically weak ${ }^{14}$.

Investment is a part of mu'amalah which means an activity of placing funds / capital in an investment product for a certain period of time hoping that the investment can grow profits. Meanwhile, the definition of investment in the Islamic perspective is all the things in which an investment activity is not against the principles of sharia (maqāsid al-ariah) ${ }^{15}$.

Investing in an Islamic perspective must pay attention to the code of ethics that becomes the signposts for every investor in placing their capital. As we know Islam has economic principles that guide it. Economic transactions in Islam must avoid gambling (masir), uncertainty (gharar), usury (al-amwäl al-ribawiyyah), buying and selling bäil, Bayi ma'düm (buying and selling of goods that are not yet owned), itikär (hoarding groceries), taghrir (influencing others), ghabn (imbalance of the object of the transaction), talaqqi al-rukbān (selling below price), tadlis and ghishsh (hiding defective goods), tanäush/najsh (high bid but not intending to buy), dharar (causing danger), rishwah (bribery), immorality and wrongdoing ${ }^{16}$.

As explained above, speculative (penny) stocks are shares (issuers) of a company that rise out of the ordinary with a very large volume of transactions. Usually, this kind of stocks are controlled by certain people for the sake of one-sided interests and something in the world of crypto traders is known as Pump and Dump ${ }^{17}$.

\section{Demand Engineering (Bai' Najasy)}

Pump and Dump is a securities transaction activity characterized by an uptrend in price movements. The increase in price was caused by a series of share purchase transactions in a sufficient number so that the price rose to the highest price level. After the stock price reaches its highest level, the bookmakers, who have an interest in the increase of the shares, sell very large volumes resulting in a very significant price drop. The goal is to gain large profits and be able to buy back the shares when the price drops (cheap).

14 "Jangan Tinggalkan Generasi yang Lemah Dalam 4 Hal | Republika Online," diakses 14 Januari 2020, https://khazanah.republika.co.id/berita/puick1374/jangan-tinggalkan-generasi-yang-lemahdalam-4-hal

15 Sakinah, "Investasi dalam Islam," Interest: Jurnal Bisnis dan Ekonomi Syariab 12, no. 1 (2014): 96-97

16 DSN MUI, "Fatwa Dewan Syari’ah Nasional No. 80/DSN-MUI/III/2011 Tentang Penerapan Prinsip Syariah dalam Mekanisme Perdagangan Efek Bersifat Ekuitas di Pasar Reguler Bursa Efek" (n.d.)

17 Yenti Afrida, "Shariah Stock Screening Process: Perspectives on Sharia Economics and Practitioners," JEBI (Jurnal Ekonomi dan Bisnis Islam) 1, no. 2 (2019): 155-66, https://doi.org/10.30868/ad.v3i2.534 
Such actions are included in the category of buying and selling tanajusy / najsy meaning that the act of bidding for goods at a higher price by parties who do not intend to buy them to create the impression that many parties are interested in buying them (demand engineering). Thus, other people will be deceived and think that the item is a good item and it is deserved to have a high price ${ }^{18}$.

This typical transaction very often occurs in the capital market which becomes a means of bringing together investors and entrepreneurs. So with the tanajusy buying and selling method, many capital market players (investors) are deceived and immediately become sudden investors (stuck) in the capital market, because if it is sold they will certainly experience losses. In Islam, the practice of buying and selling like this is certainly prohibited and falls into the category of buying and selling that is forbidden ${ }^{19}$. Rasulullab Muhammad SAW said that narrated by al-Bukhāri from 'Abdullah bin' Umar radiallahu anhuma Rasulullah said: "Rasulullah Muhammad SAW forbade buying and selling by using the way of najasy".

Besides pump and dump, in the terms of the capital market, it is also known as hype and dump, which is the sale and purchase of shares that is initiated by an uptrend accompanied by false positive information (in terms of stock traders it is known as pom-pom), so that the price of a stock reaches its highest price level ${ }^{20}$. After the price rises and even ARA (top auto reject), interested parties carry out a significant sell in a significant volume so that prices drop drastically and can even reach the bottom auto reject level. The transaction pattern is similar to the pump and dump transaction pattern aiming at creating opportunities to sell at high prices in order to make a profit.

As it is known that in the stock market, there is a maximum limit for an issuer's increase as well as its decline. The term ARA shows the upper limit of the daily increase in a stock and ARB shows the lower limit of the decline in one stock market day ${ }^{21}$. The stocks indicated as penny stock is often transacted in a form of pump and dump and also hype and dump up to the upper limit in its increase and the lower limit in its decline. These acts definitely give so many disadvantages for many people, especially for the retail investors in a capital market.

18 Ahmad Faqih, “Praktik Jual Beli Saham Syari'Ah Perspektif Hukum Islam,” Iqtisad 5, No. 1 (2018): 70

19 Inneke Wahyu Agustin, "Penerapan Prinsip-Prinsip Syariah Pada Sharia Online Trading System Menurut Fatwa Dewan Syari'ah Nasional NO.80/DSN-MUI/III/2011,” Ahkam: Jurnal Hukum Islam 7, no. 2 (2019): 309-320

20 Nevzat Eren dan Han N. Ozsoylev, "Hype and Dump Manipulation," SSRN Electronic Journal, (2006): 17-20, https://doi.org/10.2139/ssrn.948814

21 PT Bursa Efek Indonesia, "Mekanisme Perdagangan,” accessed in January 17, 2020, https://www. idx.co.id/ investor/mekanisme-perdagangan/ 
Figure 3: A limit of Auto Share Rejection

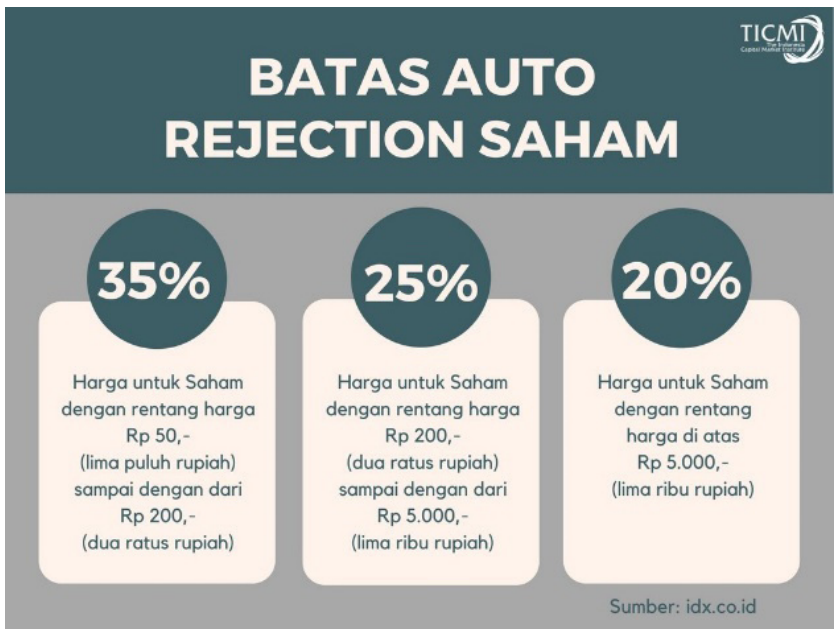

Source: www.seputarforex.com (diakses 18-01-2020)

The form of transactions that fall into the Bai 'Najasy category is buying and selling by creating fake demand/supply. These stock transactions are carried out with the aim of giving an impression to market players that a stock seems to be being traded (liquid) with a high demand/supply so that market players are interested in buying/selling the shares ${ }^{22}$.

The transaction model of creating fake demand/supply often occurs in penny stocks. There is a strong indication that a stock creating a fake demand/ supply becomes the large number of queues that can be seen in the bid price buying queue and the queue to offer price. But not long after, the bid or offer queue can suddenly disappear as a result of the cancellation or withdrawal of the order or sometimes the bid/offer price suddenly changes from the previous price by market players on penny stocks.

Another term for the three forms of transactions above is known as cornering the market in which the act of contracting a certain share in the capital market ${ }^{23}$. In the Indonesian context, this has been regulated in the Capital Market Law no. 8 of 1995 in Article 92 states that:

22 Lusi Septa Prasetia, "Implementasi Regulasi Pasar Modal Syariah Pada Sharia Online Trading System (SOTS)," Niæ̧ham 5, no. 2 (2017): 34

23 Tito Sofyan, “Analisis Yuridis Sistem Pengawasan terhadap Kejahatan Pasar Modal," Recital Review 1, no. 1 (2019): 30 
"Each Party, either individually or jointly with otherparties, is probibited to conduct 2 (two) or more Securities transactions, either directly or indirectly, causing the price of Securities on the Stock Exchange to remain, increase or decrease with the aim at influencing the Party. other to buy, sell, or hold Securities. "

Perpetrators of cornering the market in Indonesia can be threatened with imprisonment of up to ten years and a maximum fine of fifteen billion in accordance with the provisions of Article 104 of the Capital Market Law.

\section{Cover up shortages of goods (Tadlīs)}

Tadlis can be interpreted as fraud or covering up the shortage of goods being traded $^{24}$. In the present context where buying and selling uses an online system, tadlis can also be interpreted as the discrepancy between the goods being sold and the written product descriptions aimed at tricking buyers. The tadlis transaction is also included in the gharar category where its transaction does not have a certainty regarding the contract, both the quality and quantity of the goods which are the object of sale and purchase ${ }^{25}$. There are several types of tadlis transactions, such as tadlìs regarding quality, tadlis regarding quantity, tadlis regarding price, and the time of delivery ${ }^{26}$.

In Islam, tadlis clearly violates the principles of sharia in the absence of clarity of aqad or goods that are traded. Tadlis is forbidden and Allah SWT will revoke the blessings of the assets obtained by tadlis in accordance with the words of the Prophet Muhammad SAW as narrated by Imam al-Bukharī, Muslim, at-Tirmidzī, Abū Dāwud and al-Baihaqi ${ }^{27}$ :

"The seller and the buyer have khiyar (the option to cancel or continue the contract) as long as they have not been separated. If the two of them separate and act transparently (explaining the goods and prices as they are) then blessings are given in the buying and selling of both. If both of them hide (defective) each other and lie then that will scorch the blessings of buying and selling".

In the practice of buying and selling tadlīs against speculated stocks, we identify them as Front Running and Misleading Information. Front Running is an action taken by a member of the stock exchange to make a transaction to buy

24 Taufiq, "Tadlis Merusak Prinsip 'Antaradhin Dalam Transaksi,” Juris: Jurnal Ilmu Syariab 15, no. 1 (2016): 4

25 M Tholib Alawi, "Aspek Tadlis Pada Sistem Jual Beli : Analisis pada Praktik Jual Beli Pulsa

Listrik (Token) Prabayar,” Baabu Al-Ilmi 2, no. 1 (2017): 133

26 Adiwarman A. Karim, Bank Islam (Jakarta: PT. Raja Grafindo Persada, 2006), 31.

27 Gusniarti Gusniarti, "Distorsi Pasar dalam Proses Transaksi Sekuritas Syariah di Pasar Sekunder," Etikonomi 14, no. 2 (Oktober 2015): 49-51 
a particular share because of the information that the customer will buy a certain share in a large number which will certainly increase the value of the share ${ }^{28}$. The purpose of this buying action first is to take profit or reduce losses on shares that are still losing money in their portfolio.

Particular actions are certainly very unfair for other investors, especially retail. It is because very often a speculated stock when it goes up and has been accumulated in large numbers by certain people so that other investors do not get a cheap price (the term in stock: missed the train). But when other investors decide to enter and buy the shares that have been accumulated, the stock will immediately and dramatically drop even until the bid price becomes empty it makes the stocks decline so fast and of course the investors who bought on its high level (premium) will experience a loss and this is an opportunity for people who have accumulated these shares to sell goods to take profit.

The second form of tadlis is Misleading information, which is making misleading information (hoaxes) about a particular stock, both good and bad information about an issuer to influence prices in the market ${ }^{29}$. If the information made is about positive things about a particular share, the share price in the market will experience uptrend and the person who spreads the false information can easily sell the shares they own to take profit. But if false information is made regarding negative things about a particular share, the share price in the market will experience a dowtrend so that the hoax spreader can buy and own shares at a low price.

In Islam, we are commanded not to eat the property of our neighbors in an improper way ${ }^{30}$. Tadlīs actions can be categorized as taking one-sided profit in the wrong way (bail), queuing to avoid eating property by way of bail in QS. An-Nisā verse 29. Buying and selling by means of Front Running and Misleading information is an act of gambling (maisir) because the truth of the information obtained is certainly not certain (speculation) ${ }^{31}$. Speculation or drawing conclusions based only on conjecture (gambling) is certainly very contrary to the principles of sharia in QS. Al-Bāqarah verse 129 explaining that the act of gambling is a very big draw for human life and we are required to stay away from gambling.

28 Kharis Fadlullah Hana, "Dialektika Hukum Trading Saham Syariah di Bursa Efek Indonesia," TAWAZUN: Journal of Sharia Economic Law 1, no. 2 (2018): 148-60

29 Ratna Ratna, "Tinjauan Hukum Terhadap Keterbukaan Informasi dalam Hubungannya dengan Upaya Perlindungan Hukum Bagi Investor Berkaitan dengan Kasus Informasi yang Menyesatkan (Misleading Information)(Studi Pada Kasus PT. Lippo Life Tbk.)," Jurnal Hukum \& Pembangunan 36, no. 4 (2017): 404-19

30 Moh Toriquddin, "Etika Pemasaran Perspektifal-Qur'an dan Relevansinya dalam Perbankan Syari’ah," Journal de Jure 7, no. 2 (2015): 116-25

31 Egi Arvian Firmansyah, "Seleksi Saham Syariah: Perbandingan antara Bursa Efek Indonesia dan Malaysia," Jurnal Inspirasi Bisnis dan Manajemen 1, no. 1 (2017): 1-10 


\section{Influencing others (Taghrir)}

Taghrir is the origin of the word gharar which means uncertainty, consequence, disaster, danger and risk ${ }^{32}$. Taghrir, in its terminology, is doing an action without knowing the consequences that will be got from the act, or plunging into an action without knowing the risk that will be received. In economic term, taghrir is known as uncertainty or risk. In the theory of certainty, it will only create to probability, like the chance or possibility of an event about how big the chance of success or failure is. So when certainty factors are changed into uncertainty then taghrir/gharar will occur ${ }^{33}$.

So, taghrir is a contract (transaction) that contains an element of fraud due to the absence of certainty regarding the object of the contract, quality, quantity and ability to submit the object of the contract. From this understanding, of course we think that what is the difference between taghrir and tadlis? In buying and selling tadliss, the buyer does not know about the object of the contract properly (unknown to one party), while in the context of buying and selling taghrir, the buyer and seller both do not know about the object of the contract being transacted ${ }^{34}$. In Islam, the sale and purchase contract (taghrir) is forbidden because of the lack of certainty of the contract and this is explained in the hadiths narrated by Imam Muslim from Abū Hurairah RA, that the Prophet Muhammad SAW said: "For the Prophet sallallaabu 'alaibi wasallam prohibited buying and selling by throwing gravel and buying and selling that contain elements of fraud."

We all know, as the author has described above, that one indication of speculative (penny) stocks cannot be analyzed regarding the financial performance of a company listed on the stock exchange (fundamental analysis). Usually, stocks indicated as penny stocks have a very high ratio and valuation of their shares when compared to similar issuers in their sector ${ }^{35}$.

The way to measure the high cost of a stock, or the way to find the fair price of a stock is to use the ratio of share value per book value/price to book

32 Trisno Wardy Putra, “Investasi Dalam Ekonomi Islam,” Ulumul Syar'i 9, no. 2 (2018): 48-57

33 Yenni Samri Juliati Nasution, "Mekanisme Pasar Dalam Perspektif Ekonomi Islam," At-Tawassuth: Jurnal Ekonomi Islam 3, no. 1 (2018): 1-22

34 Engku Ali, Engku Rabiah Adawiah, dan Muhammad Ramadhan Fitri Ellias, "Shari'ah issues relating to Islamic Capital Market” (ISRA and Securities Commission Malaysia, 2015): $157-$ 160

35 Muhammad Jalari, Olivia Tiarthara Putri, dan Agus Marimin, "Fundamental Analysis Dalam Pengambilan Keputusan Investasi Saham Syariah Di Jakarta Islamic Index," Jurnal Education and Economics 2, no. 4 (2019): 444-469 
value (PBV) and earnings per share (EPS) ratio $^{36}$. By using these two formulas, we will find out the fair price of a stock. For example, if the industry's average price to book value in the mining sector is 0.9 times but one particular issuer has a price to book value of 10 times, 20 times or even 100 times, then we are naturally suspicious that the issuer is indicated as speculative stock meaning that it is difficult to fundamentally analyze. Likewise, when we do a technical analysis of penny stocks, it tends to be difficult to read because it is too fluctuating so that it is not uncommon for an issuer to display technical analysis indicators at all. Technically, these stock movements are also too volatile or are rarely transacted so that there is no technical analytical indicator at all.

It is clear that such actions fall into a game of uncertainty which is forbidden in Islam. In addition to buying and selling gharar like that, it can also be categorized as buying and selling of $d$ harar, like transactions that can cause damage and losses to market mechanisms, meaning that market balance will not occur and can result in a financial crisis that harms all groups ${ }^{37}$. So, Allah forbids this kind of buying and selling because the disadvantage is greater than the benefits obtained (QS. $\mathrm{Al}$-māidah verse 90). Besides that, the rule of fiqhi'yah as one of the formulas in the withdrawal of Islamic law is explained that: "Rejecting muarat (disadvantage) takes precedence over taking benefits".

In the fatwa of the National Sharia Board-Indonesian Ulama Council (known as DSN-MUI) regarding the adoption of sharia principles in the capital market, it is explained that there are two types of transactions that fall into the taghrir category in the capital market, Wash Sale and Pre-Arrange Trade. Wash Sale transactions are quasi-trading transactions that actually do not change the beneficiary of ownership. This transaction is executed to form market opinion as if the rising and falling prices of a stock are normally formed and also to create the impression that the shares are heavily traded by market players (liquid ${ }^{38}$ ).

Meanwhile, Pre-Arrange Trade is an act of conducting a buy order transaction (buy) and a sell order (sell) within the same time frame (exchanging goods) between the seller and the buyer who have made an agreement before making a transaction. The purpose of this transaction is to move a stock, either increase (uptrend), lower (downtrend), stable / fixed (sideways) or to restrain the rate of increase or decrease in a particular stock.

36 Sebastianus Laurens, "Influence Analysis of DPS, EPS, and PBV toward Stock Price and Return," The Winners 19, no. 1 (2018): 21-29

37 Agus Triyanta, "Gharar; Konsep dan Penghindarannya pada Regulasi Terkait Screening Criteria di Jakarta Islamic Index," Ius Quia Iustum Law Journal 17, no. 4 (2010): 615-32

38 Rui Ma, Hamish D Anderson, dan Ben R Marshall, "International stock market liquidity: A review," Managerial Finance 42, no. 2 (2016): 118-135 


\section{Accumulation / Hoarding of Shares (Ikhtikar)}

Ikhtikar comes from the word hakara which means persecution, storing food, collecting, storing and hoarding ${ }^{39}$. Based on its term, Ikhtikar can be interpreted as purchasing of an item while it is in a big number and storing / hoarding so that the distribution of goods in the field decreases. Thus, according to market law, the price will increase and when it increases, the stored goods are distributed and sold so that the Ikhtikar actors get a multiple profit from the issued capital ${ }^{40}$.

Ikhtikar law in the view of Islamic law is haram (prohibited) because this action is contrary to the universal values of al-Qurān which emphasize compassion and help each other in doing mu'āmalah. As confirmed in the QS. Al-Māidah verse 2 and QS. Al-Qasas verse 77:

"... And help each other in (doing) goodness and piety, and don't help in sin and enmity. Fear God, really, Allah's punishment is very heavy".

"And seek (reward) the land of the hereafter with what Allah has given you, but do not forget your part in the world and do good (to others) as Allah has done good to you, and do not do damage to the earth. Indeed, Allah does not like people who do damage".

Ikhtikar in the transaction practice in the capital market has been published in the MUI DSN Fatwa No. 80 of 2011 in this matter which is included in the Ikhtikar act and is in line with Sharia principles that are Pooling Interest and Cornering. Pooling interest is a transaction on a certain stock (securities) so that it is seen that there are many transactions by market players (liquid), either the price increases or stagnates in a certain period and the transaction (buy/sell) is usually only carried out by certain people ${ }^{41}$. These stocks usually have a daily transaction volume of almost the same in a certain guarded period. After several periods, the movement is the same and the volume is the same, only then the price is raised / increased (by certain people) indicated by the volume and valuation of daily transactions soaring drastically to take profit or make a very large number of purchases (accumulation) or to serve as a benchmark against these shares.

The second form of Ikbtikar is Cornering, cornering transactions usually occur in stocks with a small percentage of public shareholding, so there is an

39 Idris Parakkasi dan Kamiruddin Kamiruddin, "Analisis Harga dan Mekanisme Pasar dalam Perspektif Islam,” Laa Maisyir: Jurnal Ekonomi Islam 5, no. 1 (2018): 117

40 Suhrawardi K. Lubis Chairuman Pasaribu, Hukum Perjanjian dalam Islam (Jakarta: Sinar Grafika, 1994), 47.

41 Bambang Hermanto, "The Role of DSN-MUI to Ensure Shariah Compliance of Islamic Financial Transactions in Indonesia (A Political Ambiguity Perspective)," Journal of Islamic Banking and Finance 6, no. 1 (2018): 29-36 
attempt from the majority shareholder to make a quasi-supply so that the price will drop in the first session of the capital market ${ }^{42}$. Thus, public investors try to make their fortune (gambling) by performing short selling transactions (selling goods that are not yet owned/bai 'al-maksyuf) ${ }^{43}$. But in the second session of the stock market, the price suddenly went up because the majority shareholder made a very large purchase which resulted in losses for short selling investors because they have to buy back shares in session two beyond their purchases in the morning (session one).

\section{Cheating (Ghisysy)}

Ghisysy is the act of hiding the shortage of contract objects from the buyer with the aim that the buyer is pleased to carry out transactions on the object of the goods being traded. Basically, if the buyer finds out that the item is defective, he will not buy it at the seller's benchmark price. Buying and selling ghisysy can also be categorized as buying and selling Ghabn. It is like the imbalance in one transaction, especially regarding the quality of the object of the transaction of the two parties ${ }^{44}$.

In Islamic law, these transactions are prohibited because they clearly contradict the principle of maqāsidu al-syaāriah, like hif al-māl ${ }^{45}$. Allah SWT said in QS. Al-'Araf: 85 in the translation of the Ministry of Religion Year 2002

"O my people! Worship Allah. There is no god (worship) for you but Him. Surely there has come to you the clear evidence of your Lord. Perfect your measurements and scales, and don't hurt anyone. Do not do damage on earth after it was (created) well. That is better for you if you are a believer. "

The practice of buying and selling ghisysy on penny stocks is known as Marking at the close and Alternate trade. Market at the close or the formation of the closing price aims to adjust the price at the closing time, if the price is going down but what you want is to go up, at the time of market close, a buy order is

42 M Nasyah Agus Saputra, "Pasar Modal Syariah di Indonesia," Al-Qanun: Jurnal Pemikiran dan Pembaharuan Hukum Islam 17, no. 1 (2014): 85-103

43 H Syahrul, "Bursa Efek dalam Ekonomi Islam," Diktum: Jurnal Syariah dan Hukum 11, no. 1 (2013): 65-81

44 Syamsuddin Arif, "Epistemologi Halal dan Aplikasinya," Dirasat: Jurnal Studi Islam dan Peradaban 14, no. 02 (2019): 1-24

45 Andri Seomitra, Hukum Ekonomi Syariah dan Fiqh Muamalah di Lembaga Kenangan dan Bisnis Kontemporer (Jakarta: Prenadamedia Grup, 2019), 196. 
made so that the stock is not closed in a weakened state. Likewise, if the stock rises even though what you want is to fall, then at the market close, a sell order is carried out so that the stock price is closed in a weakened state compared to the previous day's closing.

Alternate trade transactions are transactions carried out by market players by alternating buy and sell transactions, meaning that the person whose transaction is the same (person or often called a dealer). The aim is to form public opinion regarding the liquidity of these shares because the volume and valuation of daily transactions are quite large. Thus, other market players will be interested in buying and selling the shares.

\section{Conclusion}

One of the big mistakes of Jiwasraya insurance is the placement of investment funds in assets that have a high risk, such as stocks and mutual funds. As a company that collects funds from the public (customers), Jiwasraya's insurance management should be more careful in making investment fund placement decisions.

Indeed, penny stocks sometimes give a promise giving big returns in a short time, but in the current condition where the global economy is in uncertainty due to economic instability marked by trade wars and heating up conditions in the Gulf countries, insurance business activists and investment managers should be more careful in carrying out investment activities in high risk sectors but prefer having safe haven investment instruments.

Investments in highly volatile stocks are very dangerous for everyone, both institutional investors and retail investors, because transactions in these stocks are full of uncertainty. So, it is natural that stocks like this cannot be analyzed both fundamentally and technically, especially when price movements are different from the reality (fundamentals), so that Islam as a religion has an interest in protecting its adherents by prohibiting transactions on stocks that have fluctuative and high prices because it is clear that these shares contain elements that are contrary to the aim of the Shari'a being revealed to humans (maqāsidu al-ariab). Stocks that have a small market capitalization and are not accompanied by adequate company growth are very risky for their shares to fall into the category of stocks that have high price fluctuations containing elements of maisir, najasy, gharar, ghisysy, ikhtikar, taghrir and tadlis for the perpetrators. 
References

A. Patoni, A. Lasmana. "The Effectof Stock Price and Trading Frequency of The Bid-Ask Spread (Empirical Study on A Manufacturing Company Doing Stock Split In Indonesian Stock Exchange During 2009-2014)." Jurnal Akunida 1, no. 2 (2015).

Afrida, Yenti. "Shariah Stock Screening Process: Perspectives on Sharia Economics and Practitioners." JEBI (Jurnal Ekonomi dan Bisnis Islam) 1, no. 2 (2019): 155-66 https://doi.org/10.30868/ad.v3i2.534

Agustin, Inneke Wahyu. "Penerapan Prinsip-Prinsip Syariah Pada Sharia Online Trading System Menurut Fatwa Dewan Syariah Nasional No.80/Dsn-Mui/ Iii/2011." Abkam: Jurnal Hukum Islam 7, no. 2 (2019): 309-32. https:// doi.org/10.1017/CBO9781107415324.004

Alawi, M Tholib. “Aspek Tadlis Pada Sistem Jual Beli : Analisis pada Praktik Jual Beli Pulsa Listrik (Token) Prabayar." Baabu Al-Ilmi 2, no. 1 (2017).

Ali, Engku, Engku Rabiah Adawiah, dan Muhammad Ramadhan Fitri Ellias. "Shari'ah issues relating to Islamic Capital Market." ISRA and Securities Commission Malaysia, (2015).

Arif, Syamsuddin. "Epistemologi Halal dan Aplikasinya.” Dirasat: Jurnal Studi Islam dan Peradaban 14, no. 02 (2019).

Bursa Efek Indonesia. “Mekanisme Perdagangan.” Accessed in January 17, 2020. https://www.idx.co.id/investor/mekanisme-perdagangan/

Carolina, Debi. “Analisis Penilaian Kewajaran Harga Saham dengan Menggunakan Pendekatan Fundamental Pada PT. Panin Sekuritas Tbk". Jurnal Media Wahana Ekonomika 15, no. 2 (2018).

Chairuman Pasaribu, Suhrawardi K. Lubis. Hukum Perjanjian dalam Islam. Jakarta: Sinar Grafika, 1994.

CNBC Indonesia. "Apa Itu Saham Gorengan? Ini Definisi, Ciri-ciri, dan Tipsnya." Accessed in January 15, 2020. https://www.cnbcindonesia.com/ investment/20200102162008-21-127172/apa-itu-saham-gorengan-inidefinisi-ciri-ciri-dan-tipsnya

CNBC Indonesia. “Dari Jokowi hingga Sri Mulyani Soroti Saham Gorengan," 2020. https://www.cnbcindonesia.com/market/20200103092703-17- 
127301/dari-jokowi-hingga-sri-mulyani-soroti-saham-gorengan

CNN Indonesia. "Kronologi Kasus Jiwasraya, Gagal Bayar Hingga

Dugaan Korupsi," 2020. https://www.cnnindonesia.com/

ekonomi/20200108111414-78-463406/kronologi-kasus-jiwasraya-gagal-

bayar-hingga-dugaan-korupsi

DSN MUI. Fatwa Dewan Syariah Nasional Nomor 80/DSN-MUI/III/2011

Tentang Penerapan Prinsip Syariah dalam Mekanisme Perdagangan Efek

Bersifat Ekuitas di Pasar Reguler Bursa Efek (n.d.)

Eren, Nevzat, dan Han N. Ozsoylev. "Hype and Dump Manipulation." SSRN Electronic Journal, (2006): 17-20. https://doi.org/10.2139/ssrn.948814

Faqih, Ahmad. "Praktik Jual Beli Saham Syari'Ah Perspektif Hukum Islam." Iqtisad 5, no. 1 (2018): 70 https://doi.org/10.31942/iq.v5i1.2207

Firmansyah, Egi Arvian. "Seleksi Saham Syariah: Perbandingan antara Bursa Efek Indonesia dan Malaysia." Jurnal Inspirasi Bisnis dan Manajemen 1, no. 1 (2017).

Gusniarti, Gusniarti. “Distorsi Pasar dalam Proses Transaksi Sekuritas Syariah di Pasar Sekunder.” Etikonomi 14, no. 2 (2015).

Hana, Kharis Fadlullah. "Dialektika Hukum Trading Saham Syariah di Bursa Efek Indonesia." TAWAZUN: Journal of Sharia Economic Law 1, no. 2 (2018).

Hermanto, Bambang. “The Role of DSN-MUI to Ensure Shariah Compliance of Islamic Financial Transactions in Indonesia (A Political Ambiguity Perspective)." Journal of Islamic Banking and Finance 6, no. 1 (2018).

Jalari, Muhammad, Olivia Tiarthara Putri, dan Agus Marimin. "Fundamental Analysis Dalam Pengambilan Keputusan Investasi Saham Syariah di Jakarta Islamic Index." Jurnal Education and Economics 2, no. 4 (2019).

Karim, Adiwarman A Bank Islam. Jakarta: PT. RajaGrafindo Persada, 2006.

Laurens, Sebastianus. "Influence Analysis of DPS, EPS, and PBV toward Stock Price and Return." The Winners 19, no. 1 (2018).

Ma, Rui, Hamish D Anderson, dan Ben R Marshall. "International stock market liquidity: A review." Managerial Finance 42, no. 2 (2016). 
Muhammad, Abdulkadir. Hukum dan Penelitian Hukum. Bandung: Citra Aditiya, 2004.

Nasution, Yenni Samri Juliati. "Mekanisme Pasar Dalam Perspektif Ekonomi Islam." AT-TAWASSUTH: Jurnal Ekonomi Islam 3, no. 1 (2018).

Parakkasi, Idris, dan Kamiruddin Kamiruddin. "Analisis Harga dan Mekanisme Pasar dalam Perspektif Islam.” Laa Maisyir: Jurnal Ekonomi Islam 5, no. 1 (2018).

Prasetia, Lusi Septa. "Implementasi Regulasi Pasar Modal Syariah Pada Sharia Online Trading System (SOTS).” Nizham 5, no. 2 (2017).

Putra, Trisno Wardy. “Investasi dalam Ekonomi Islam.” Ulumul Syar’ 9, no. 2 (2018).

Ratna, Ratna. "Tinjauan Hukum Terhadap Keterbukaan Informasi dalam Hubungannya Dengan Upaya Perlindungan Hukum Bagi Investor Berkaitan Dengan Kasus Informasi Yang Menyesatkan (Misleading Information)(Studi Pada Kasus Pt. Lippo Life Tbk.)." Jurnal Hukum \& Pembangunan 36, no. 4 (2017).

Sakinah. "Investasi dalam Islam." Interest: Jurnal Bisnis dan Ekonomi Syariah 12, no. 1 (2014).

Saputra, M Nasyah Agus. "Pasar Modal Syariah di Indonesia." Al-Qanun: Jurnal Pemikiran dan Pembaharuan Hukum Islam 17, no. 1 (2014).

Siregar, Sawaluddin. "Perspektif Hukum Islam Mengenai Mekanisme Manipulasi

Pasar dalam Transaksi Saham di Pasar Modal." Yurisprudentia 3, no. 2 (2017).

Seomitra, Andri. Hukum Ekonomi Syariah dan Figh Muamalah di Lembaga Keuangan dan Bisnis Kontemporer. Jakarta: Prenadamedia Grup, 2019.

Sofyan, Tito. "Analisis Yuridis Sistem Pengawasan terhadap Kejahatan Pasar Modal." Recital Review 1, no. 1 (2019).

Syahrul, H. "Bursa Efek Dalam Ekonomi Islam." Diktum: Jurnal Syariah dan Hukum 11, no. 1 (2013).

Tanjung, Didin Hafidudin dan Hendri. Manajemen Syariah dalam Praktik. Jakarta: Gema Insani Press, 2003. 
Taufiq. “Tadlis Merusak Prinsip ‘Antaradhin Dalam Transaksi.” Juris: Jurnal Ilmu Syariah 15, no. 1 (2016).

Toriquddin, Moh. "Etika Pemasaran Perspektifal-Qur'an dan Relevansinya dalam Perbankan Syari’ah.” Journal de Jure 7, no. 2 (2015).

Triyanta, Agus. "Gharar; Konsep dan Penghindarannya pada Regulasi Terkait Screening Criteria di Jakarta Islamic Index." Ius Quia Iustum Law Journal 17, no. 4 (2010): 615-32

Wiwiek Mardawiyah Daryanto. Wawan Rahardianto. "Measuring the Financial Health Performance of Life Insurance Company in Indonesia: Case Study During the Period of Before and After the Implementation of Peraturan Otoritas Jasa Keuangan, Nomor 71/POJK.05/2016." IPMI: International Journal of Business Studie 3, no. 2 (2019.

Wulan, Dewi Cahya, Siti Ragil Handayani, dan Ferina Nurlaily. "Analisis Abnormal Return dan Trading Volume Activity Terhadap Pengumuman Unusual Market Activity ( Studi pada Perusahaan yang Terdaftar dalam Pengumuman Unusual Market Activity di BEI Tahun 2015-2017 )." Jurnal Administrasi Bisnis (JAB) 61, no. 1 (2018).

“Astaga! Rasio Kecukupan Modal Jiwasraya Minus 850\%.” Accessed in January 17, 2020. https://www.cnbcindonesia.com/market/20191218160147-17124158/astaga-rasio-kecukupan-modal-jiwasraya-minus-850

“Bobrok dari 2004, Ini Kronologi Jiwasraya Hingga Default." Accessed in January 16, 2020. https://www.cnbcindonesia.com/market/20191228185156-17126264/bobrok-dari-2004-ini-kronologi-jiwasraya-hingga-default

"Jangan Tinggalkan Generasi yang Lemah Dalam 4 Hal | Republika Online." Accessed in January 14, 2020. https://khazanah.republika.co.id/berita/ puick 1374/jangan-tinggalkan-generasi-yang-lemah-dalam-4-hal 